Historic, Archive Document

Do not assume content reflects current scientific knowledge, policies, or practices. 

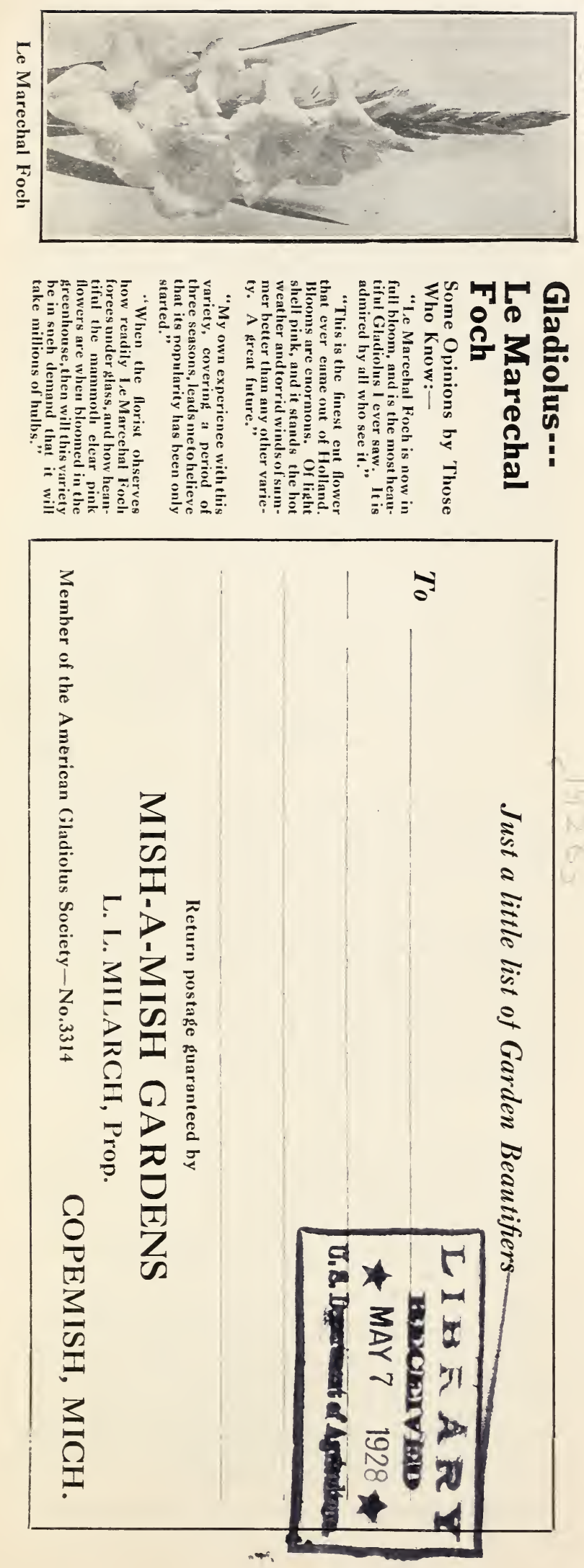


\section{TERMS OF BUSINESS.}

First-Cash must accompany order. No orủers filied for less than $\$ 1.00$.

Second-Remittance may be sent in any manner most convenient to the purchaser.

Third-Prices quoted include postage or express charges, except where noted.

Fourth-We guarantee the safe arrival of goods by mail or express, and will use careful methods in filling orders with stock of known vitality, and superior merit. If any stock doesn't prove true to riame we will replace same free of charge or refund your money. But we will not be responsible for snortages or other causes beyond our control. Errurs should be reported at once.

Fifth-Size of bulbs. Orders will be filled with first size bulbs, when out of first size, second or third sizes will be sent and more of them, unless mentioned when sending the order. If out of varieties ordered we will substitute with as good or better of similar color unless mentioned.

Sixth-Filling orders. We try to send orders just as soon as possible, filling them in rotation as we receive them. Many times your order goes out the same day we receive it.

Seventh-Complaints. In case any order fails to meet your approval, as error or oversight may tappen when in a hurry, we will thank you if you will report to us and give us the first chance to correct same.

\section{Dahlias}

A. D. LIVONA, (Show)-Fine lavender pink, each $20 \mathrm{c} ; 3$ for $45 \mathrm{c}$; 6 for $75 \mathrm{c}$;

.doz. $\$ 1.20$

AMBASSADOR, (H. C.) - Yellow with salmon amber and pink, large flower, each ................\$2.50

ELAUER STRUMPF, (Dec.)-A bluish purple, each . .................................................................. $0 \mathrm{cc}$

BRIDE'S BOQUET, (Cac.)-A white cactus, profuse bloomer, each ...............................................50 c

CARR'S PINK, (Cac.) - Very light pink, each....50c

CHAMPAGNE, (Dec.)-Dull golden champagne, one of the largest, each ...........................................\$2.5U

CRONO LEO, (H. C.) - A rich flame color, eacn $\$ 2.50$; 3 for $\$ 5.05 . . . \ldots \ldots \ldots \ldots \ldots . . . . . . . . . . . . . . . . .6$ for $\$ 9.95$

DARLENE, (Dec.) - Live shell pink, white center, each $25 \mathrm{c}$; 3 for $60 \mathrm{c}$; 6 for $95 \mathrm{c}$; doz. $\$ 1.50$; per 100 . ...................................................\$8.50

DR. TEVIS, (Dec.)-A combination of salmon rose and bronze, each ...............................................\$1.00

GEO. WALTERS, (H. C.)-Salmon pink and yellow each . ...........................................................\$2.00

KING OF THE AUTUMN, (Dec.)-A buff yellow, each ..............................................50c; 3 for $3 \mathrm{i} .05$

KLONDYKE, (Cac.)-Deep lemon, shaded darker................................................... each $\$ 1.50$

LAVENDER QUEEN, (Dec.)-A fine lavender, each .......................................... $\$ 1.50 ; 3$ for $\$ 3.05$

LITTLE GEM, (Pompom Show)-Deep lavende: each..............25c; 3 for $60 \mathrm{c} ; 6$ for $95 \mathrm{c}$; doz. $\$ 1: 50$

IAUD ADAMS, (Show) - White tinted pink, each $.25 c$; 3 for $60 \mathrm{c}$; 6 for $95 \mathrm{c}$; doz. $\$ 1.5$ ?

MINA BURGLE, (Dec.)-Scarlet. Each...........25c; 3 for $60 \mathrm{c}$; 6 for $95 \mathrm{c}$; doz. $\$ 1.50$ 
MRS. CARL SALBACH, (Dec.)-Mallow piik, each …....................... $75 \mathrm{c} ; 3$ for $\$ 1.55 ; 6$ for $\$ 2.95$

MiRS. ETHEL, E. T. SMITH (Cac.) -A fine creamy white, each .......................................50c; 3 for $\$ 1.05$

MRS. I. DE VAN WARNER, (Dec.)-Mauve pink, each...... $\$ 1.50 ; 3$ for $\$ 3.05 ; 6$ for $\$ 6.95$; doz. $\$ 9.00$

MRS. J. M. ROOT, (Dec.) -A canary yelluv each .............................................................\$3.50

MRS. NATHANIEL SLOCOMB, (Dec.)-Deep yeilow, extra fine, each ...........................................\$1.50

PATRICK OMARA, (Dec.)-A buff tinged neyron rose, each.

PKIDE OF CALIFORNIA, (Dec.)--Vivid red, strong grower, fine flower, each ....................25c; 3 for $60 \mathrm{c}$; 6 for $95 \mathrm{c}$; doz. $\$ 1.50$; per $100, \$ 8.50$

ROSA NELL, (Dec.)-Fine rose color, extra larga flower, each...... \$1.50; 3 for $\$ 3.05 ; 6$ for $\$ 5.95$; doz. $\$ 9.00$.

SHANNON, (Dec.)-Bold golden orange, each $\$ 1.50 ; 3$ for $\$ 3.05 ; 6$ tor $\$ 5.95$

SPRINGFIELD, (Cac.)-A rich amarathine red, each ……......................25c; 3 for $60 \mathrm{c}$; doz. $\$ 1.50$

S'TORM KING, (Show)-A beautiful white, fine bloomer, each $15 \mathrm{c}$; 3 for $35 \mathrm{c}$; 6 for $55 \mathrm{~s}$; doz. $95 \mathrm{c}$; per $100, \$ 5.00$.

WORLD'S BEST WHITE (Dec.)-One of the best pure white, each ...................................................\$3.00

IELLOW DUKE, (Dec.)-A golden yeliow, each 35 ; 3 for 75 c; 6 for $\$ 1.35$; doz. $\$ 2.10$; per $i 00$, $\$ 12.50$.

MIXED COLORS-15 for $\$ 1.10 ; 18$ for $\$ 1.25$, per $100, \$ 5.00$. 25 at the 100 rate, 25 and the 100 rate F. O. B. Parcel Post or Express.

\section{CULTURE}

Plant in any good soil about six inches deep, lay the roots on the side with the eye up. Arter piant has four leaves pinch out the center, and side shoots will form, leaving four strong shoots, one bud to each branch, and you will have some fine blooms. If you want some choice blooms leave fulur buds to each plant, pinch off all others. When buds begin to show, water freely with liquid manure, also using a little bone dust and hard wood ashes. Scatter around the plant, not too close, and work it into the soil. As soon as the frost has hilled ine fcliage dig the roots carefully, cut off the tops, place the roots up-side down in a box or barrel and store in a good cellar where they won't freeze. The following spring you may divide the roots and piant them.

\section{Gladioli or Gladiolus}

PLANTING-Plant in any good soil in full surlight away from trees or shrubs, two or three inches deep in clay soil, four to five inches in sandy soils. Don't use any fresh manures when planting. You may use bone dust and pulverized sheep manures right after planting bulbs and rake it in the ground and another dressing when spikes begin to show. Or use any liquid manures about the color of strong: tca. In dry season water freely. Make the rows to suit and set the bulbs four, six or eight inches apart in the row.

BLOOMING-For best results cut the spihes when the first two flowers open and let them bloom 
in the house, leave as many leaves as possibie on the plant to mature the buib; remove wilted blowsoms; with a sharp knife cut about an inch of tire stem off each morning, making a slanting cut; giva tliem fresh water dally.

DIGGING AND STORING-In the fall before hard frost, dig the bulbs, cut off the tops close to the bulbs, dry well in the air and sunshine before storins in the cellar. Any good dry storage of about 40 degrees is right. Any good shallow box will do. Lon't put bulbs over four inches deep in boxсs. You may cross pile your boxes which will give them plenty of air. Watch your bulbs closely, they wiil fireze as quick as potatoes. In about thirty days you may clean off the old bulb from the bottom, and if you care to save the bulblets about the size oi pepper kernels, place them in dry sand in little boxes not air tight, planting them about two to three inches deep the next spring. With good care they will blocm the second year.

All bulbs offered per 100 are sold F. O. B. Express or Parcel Post collect.

\section{VARIETIES.}

ALBANIA-Very fine white large flower. each 15 c; 3 for $35 c ; 6$ for 55 c; doz. 95

ALICE TIPLADY - A beautiful orange color, each $10 c$; 3 for $24 c ; 6$ for $35 c$; doz. 60 c; per 100 . $\$ 3 . ; 0$

ALMA GLUCK-Orange and scarlet, very early, each..........25c; 3 for 60c; 6 for 95c; doz. $\$ 1.50$

AMERICAN BEAUTY, Diners-Dark pink, fina, six to ten blossoms open at a time, each $25 \mathrm{c}$; 3 for $60 \mathrm{c}$; 6 for $95 \mathrm{c}$; doz. $\$ 1.50$

ANNETTA-A lavender, each 25c; 3 for $60 \mathrm{c} ; 6$ for $95 \mathrm{c}$; doz. $\$ 1.50$.

ALTON-A fine ruffled orange, each 25c; 3 for $60 \mathrm{c}$; 6 for $95 \mathrm{c}$; doz. $\$ 1.50$.

ANTHONY B. KUNDERD-Intensely ruffled, a creamy pink, each $40 \mathrm{c}$; 3 for $\$ 1.00 ; 6$ for $\$ 1.60$; doz. $\$ 2.50$.

BUTTERFLY-Pale salmon yellow, each 10c; 3 for $24 c ; 6$ for $35 c$; doz. 60 c.

BIRON HULO-Bluish purple, each 10c; 3 for $24 c$; 6 for $35 \mathrm{c}$; doz. 60 c.

BYRON L. SMITH-One of the best lavender pink, each .............25 ; 3 for $60 c ; 6$ for $95 \mathrm{c}$; doz. $\$ 1 . j 0$

CAPTAIN BOYNTON-Light lavender with purple blotch on lower petal, each 30c; 3 for $55 \mathrm{c}$; 6 for $\$ 1.15$; doz. $\$ 2.80$.

CARMEN SYLVIA-Pure white, each 15c; 3 fo: $35 c ; 6$ for $55 \mathrm{c}$; doz. $95 \mathrm{c}$.

CÂTHERINE COLEMAN-Geranium pink, each $50 \mathrm{c}$

COURONNA-Large red, coal black throat, each 20 c; 3 for $45 \mathrm{c}$; 6 for $75 \mathrm{c}$; doz. $\$ 1.20$

CRIMSON GLOW-Deep velvety red, early, each $15 \mathrm{c} ; 3$ for $35 \mathrm{c}$; 6 for $55 \mathrm{c}$; doz. $95 \mathrm{c}$

CRINKLES-Deep peach blossom pink, intensely ruffled, each ..................................75 $\mathrm{c} ; 3$ for $\$ 1.55$

DIANA-Bright red, tall spike, early, eacn $15 c$; 3 for 35c; 6 for 55c; doz. 9oc

DOROTHY McKIBBIN-Fine large pink, eariy each ..........................................10 c; 3 for $24 \mathrm{c}$

DROCOCEPHALUS-A wild gladioli species, an oddity, each ..................................................25 c

DR. VAN FLEET-Rose pink, tall plant, fine, each 30 c; 3 for 65 c; 6 for $\$ 1.15$; doz. $\$ 1.80$

DUCHESS OF YORK-Tall bluish purple, each $30 c$; 3 for $65 c ; 6$ for $\$ 1.15$; doz. $\$ 1.80$

E. J. SHALOR-Deep rose pink, early, very attractive, ruffled, each 20c; 3 for $45 c ; 6$ foi $75 c$; doz. $\$ 1.20$. 
EVELYN KIRTLAND-Rose pink fading to shell pink, fine, each $20 \mathrm{c} ; 3$ for $45 \mathrm{c} ; 6$ for $75 \mathrm{c} ; \mathrm{doz} . \$ 1.20$

EMPRESS OF INDIA-Deep purplish red, each .15c; 3 for $35 c$; 6 for $55 c$; doz. 9 čc

ELIZABETH TABOR-Extra early, delicate r joy pink with crimson blotch, each

$.25 \mathrm{c} ; 3$ for $60 \mathrm{c} ; 6$ for $95 \mathrm{c}$; doz. $\$ 1.50$

EXQUISITE-American beauty rose color, each 50 ; 3 for $\$ 1.05$

GIANT NYMPH-Tall light pink, each.

$25 \mathrm{c}$; 3 for $60 \mathrm{c} ; 6$ for $95 \mathrm{c}$; doz. $\$ 1.50$

GOLDEN MEASURE-Large yellow, each.

$.25 c$; 3 for 60 c; 6 for 95 c; doz. $\$ 1.50$

GOLDEN SWALLOW-Ruffled yellow, each $50 \mathrm{c} ; 3$ for $\$ 1.05$

GOLD-Pure golden yellow, each

$.25 \mathrm{c}$; 3 for $60 \mathrm{c}$; 6 for $95 \mathrm{c}$; doz. $\$ 1.50$

GOVERNOR HANLEY-Earliest red, each

$20 c$; 3 for $45 c$; 6 for $75 c$; doz. $\$ 1.20$

HALLEY-Large pink, early, each

$10 \mathrm{c} ; 3$ for $24 \mathrm{c}$; 6 for $35 \mathrm{c}$; doz. $60 \mathrm{c}$; per $100, \$ 3.00$

IW A-Pink with dark throat, each ............................50

JACK LONDON-Salmon pink with red lines, each ..............20c; 3 for $45 c$; 6 for $75 c$; doz. $\$ 1.20$

JEWELL-Pink with yellow throat, each. $30 \mathrm{c} ; 3$ for $65 \mathrm{c} ; 6$ for $\$ 1.15$; doz. $\$ 1.80 ; 100 \$ 10.50$

KUNDERDII GLORY-A creamy pink, ruifled, $15 \mathrm{c}$; 3 for $35 \mathrm{c}$; 6 for $55 \mathrm{c}$; doz. $95 \mathrm{c}$; per $100 \$ 5.00$

LE M. FOCH-Light lavender pink, large flower, fine, each ................................................................10e ; 3 for $24 \mathrm{c}$; 6 for $35 \mathrm{c}$; doz. $60 \mathrm{c}$; per $100 \$ 3.00$

L'IMMACULEE-Pure white, long spike, fine, each 20 c; 3 for $45 \mathrm{c}$; 6 for $75 \mathrm{c}$; doz. $\$ 1.20$; per $100 \$ 7.00$

LOVES FEUER - Live red, each

$.15 \mathrm{c}$; 3 for $35 \mathrm{c}$; 6 for $55 \mathrm{c}$; doz. $95 \mathrm{c}$

MARIE KUNDERD-A wonderful white, ruftled, carly, each........25c; 3 for $60 \mathrm{c} ; 6$ for $95 \mathrm{c}$; doz. $\$ 1.50$

MARY'PICKFORD-A creamy white, each... $15 \mathrm{c} ; 3$ for $35 \mathrm{c}$; 6 for $55 \mathrm{c}$; doz. $95 \mathrm{c}$

MARNIA - Live golden orange, golden throat, strong grower, each ............................. $\$ 1.25 ; 3$ for $\$ 2.55$

IAIDENS BLUSH-Blush pink, very early, each $10 \mathrm{c}$; 3 for $24 \mathrm{c} ; 6$ for $35 \mathrm{c}$; doz. $60 \mathrm{c}$; per $100 \$ 3.00$

IiARSHALL FOCH-Salmon pink, each

$15 \mathrm{c}$; 3 for $35 \mathrm{c}$; 6 for $55 \mathrm{c}$; doz. 9 c c

MASTER WEIBERTUS-Lilac blue, ex. tall spike, each $10 \mathrm{c} ; 3$ for $24 \mathrm{c}$; 6 for $35 \mathrm{c}$; doz. $60 \mathrm{c} ; 100 \$ 3.00$

MiNG TOY-Deep buff yellow, large flower, each $25 \mathrm{c}$; 3 for $60 \mathrm{c}$; 6 for $95 \mathrm{c}$; doz. $\$ 1.50$

MiSS SPOKANE-Orange salmon color, each $.15 \mathrm{c} ; 3$ for $35 \mathrm{c} ; 6$ for $55 \mathrm{c}$; doz. $95 \mathrm{c}$

MRS. DR. NORTON-Finest creamy pink and yellow combination, each 20 c; 3 for $45 c$; 6 for $75 c$; doz. $\$ 1.20$; per $100 \$ 8.00$

liRS. FRANK PENDLETON-Rosy pink with oxblood blotch, each ….........................................15 c; 3 for 35c; 6 for 55c; doz. 95e; per $100 \$ 5.00$

IIRS. F. C. PETERS-Rose lilac with crimson blotch, each 25c; 3 for $60 \mathrm{c} ; 6$ for $95 \mathrm{c}$; doz. $\$ 1.50$

MRS. H. E. BOTHIN-Light geranium pink, heavily ruffled, each .......................................................15c; 3 for $35 \mathrm{c}$; 6 for $55 \mathrm{c}$; doz. $95 \mathrm{c}$; per $100 \$ 5.00$

MRS. LEON DOUGLAS-Begonia rose, fine flower. each $50 \mathrm{c} ; 3$ for $\$ 1.05 ; 6$ for $\$ 1.95$; doz. $\$ 3.00$

MYRA-Salmon pink, strong grower, large flower, each $10 \mathrm{c} ; 3$ for $24 \mathrm{c} ; 6$ for $35 \mathrm{c}$; doz. $60 \mathrm{c} ; 100 \$ 3.00$

ODIN-Salmon with deep red blotch on lower petal, large flower, early, each

15 c; 3 for $35 c$; 6 for 55 c; doz. 95 c; per $100 \$ 5.00$ 
ORANGE QUEEN-A warm copper orange, fine flower on straight spike, each

$.50 \mathrm{c} ; 3$ for $\$ 1.05 ; 6$ for $\$ 1.95$; doz. $\$ 3.00$

PEACE-White with lilac throat, each $10 c$; 3 for $24 c$; 6 for $35 c$; doz. $60 c$; per $100, \$ 3.00$

PEACH ROSE-Rose pink, one of the best, very choice, each 35c; 3 for $75 c ; 6$ for $\$ 1.35$; doz. $\$ 2.10$

F'INK PERFECTION-Pale rosy pink, large flower, each .......... 20c; 3 for $45 c$; 6 for $75 c$; doz. $\$ 1.20$

FRIMULINA SPECIES-A wild Gladioli from Africa, each .................10c; 3 for $24 c$; 6 for 35 c

PRINCE OF WALES-A beautiful salmon pink, ex. fine, each 15c; 3 for $35 \mathrm{c}$; 6 for $55 \mathrm{c}$; doz. $95 \mathrm{c}$; per $100 \$ 5.00$.

PURPLE GLORY -Velvety maroon red, extra large flower, each $25 c ; 3$ for $60 c ; 6$ for $95 c$; doz. $\$ 1.50$

PYTHIA - A gigantic red, each $.15 \mathrm{c}$; 3 for $35 \mathrm{c} ; 6$ for $55 \mathrm{c}$; doz. 95 c

QUINTON-Coral pink, large flower, strong grower, each $.50 \mathrm{c} ; 3$ for $\$ 1.05$

FEMEMBRANCE-Geranium pink, each $\ldots \ldots \ldots \ldots \ldots . .25 c$; 3 for $60 \mathrm{c} ; 6$ for $95 \mathrm{c}$; doz. $\$ 1.50$

RICHARD DINER-Rose salmon with creamy yellow throat, each

$20 c$; 3 for $45 c$; 6 for $75 c$; doz. $\$ 1.20$

KUSE LUSAINTA-Rose pink shading to creamy yellow, each

$15 c$; 3 for $35 c ; 6$ for $55 c$; doz. 95 ; ; per $100 \$ \ldots .0 . \ldots$

KUSE PRECOSE-A beautiful combination of pink and salmon, each......... 25c; 3 for $60 c$; doz. $\$ 1.50$

1310 ROSE-Rich rose color, fine, each $15 c$; 3 for $35 c$; 6 for $55 c$; doz. $95 c$; per $100 \$ 5.00$

SAN PARIEL-Apricot pink with white throat, considered one of the best glads, each...............\$1.50

SCHWABEN-Lemon yellow, carmine blotch, each $10 \mathrm{c}$; 3 for $24 \mathrm{c}$; 6 for $35 \mathrm{c}$; doz. $60 \mathrm{c}$; per $100 \$ 3.00$

SCARLET WONDER-A mammoth scarlet, each.... 50c; 3 for $\$ 1.05$

SOUVENIR-A deep yellow prim, strong grower, each ................15c; 3 for $35 \mathrm{c} ; 6$ for $55 \mathrm{c}$; doz. $95 \mathrm{c}$

STALWART-A creamy yellow, tall plant, each $75 \mathrm{c}$; 3 for $\$ 1.55$; 6 for $\$ 2.95$

SUN SE'T GLOW-Scarlet prim, good spike, each $25 c$; 3 for $60 c$; 6 for $95 c$; doz. $\$ 1.50$

iHISTLE-A large rosy red, each.

$25 c$; 3 for $60 c$; 6 for $95 c$; doz. $\$ 1 . j 0$

TYRIAN BEAUTY-Large flower of pure tyrian rose, each........15c; 3 for $35 c$; 6 for $55 c$; doz. $95 c$

YELLOW TREASURE-A rich clear yellow, each $.20 c$; 3 for $45 c$; 6 for $75 c$; doz. $\$ 1.20$

\section{MIXED OF MANY CHOICE COLORS PREPAID}

Large size bulbs, each $5 \mathrm{c} ; 3$ for $12 \mathrm{c} ; 6$ for $19 \mathrm{c}$; doz. 30c; per $100 \$ 2.50$. Small blooming size, 100 for $\$ 1.10 ; 125$ for $\$ 1.25$; per $1000 \$ 8.00$.

\section{F. O. B. COPEMISH.}

Large size bulbs, $\$ 2.00$ per $100 ; \$ 18.00$ per i000; 250 at the 1000 rate. Small blooming size, T5e per $100 ; \$ 6.00$ per 1000,250 at the 1000 rate.

\section{NOTICE.}

All orders will be filled up to June first. After tinat date all bulbs will be planted.

\section{Iris}

This list includes the intermediate, early and late bearded flag Iris. Every collection sholil have some of each of the three seasons to prolong 
trie blooming season. Every variety listed is uistiinct and fine. The number before the name denotes the rating, 100 being perfect: $\mathrm{S}$. means standards or upper petals; F. means falls or lower petals. Each and dozen lots prepaid; 100 lots F. O. B.; 25 at tile 100 rate.

\section{EARLY BEARDED FLAG IRIS.}

78-AMAS-A handsome grand flower, S., rich blue, F., violet, each .............................................15e; 3 for $35 \mathrm{c}$; 6 for $55 \mathrm{c}$; doz. $95 \mathrm{c}$; per $100 \$ 5.00$

78-KOCHII-S. and F. A rich claret purple, each $15 \mathrm{c}$; 3 for $35 \mathrm{c} ; 6$ for $5 \tilde{c} \mathrm{e}$; doz. 95̃ ; $100, \$ 5.00$

76-FLORINTENA ALBA - S. and F. A silvery white, large flower, each

$15 \mathrm{c}$; 3 for $35 \mathrm{~s}$; 6 for $55 \mathrm{c}$; doz. $95 \mathrm{c} ; 100 \$ 5.00$

78-DOROTHEA-S. and F. Robin egg blue, each $15 \mathrm{c}$; 3 for $35 \mathrm{~s} ; 6$ for $55 \mathrm{c}$; doz. $95 \mathrm{c} ; 100 \$ 5.00$

78-ORRIFLAMME, S. light blue, F. rich vioiet purple, fragrant, each..

........50c; 3 for $\$ 1.05 ; 6$ for $\$ 1.95$; doz. $\$ 3.00$

8j-FIRMAMENT-(Grochner, 1920.) F. are turquoise blue, S. violet purple, orange beard, large flower, one of the finest early Iris, each....\$1.00, 3 for $\$ 2.05 ; 6$ for $\$ 3.95$; doz. $\$ 6.00$

66-HELGE-S. golden yellow, F. lemon yeilow, $10 \mathrm{c}$; 3 for $24 \mathrm{c}$; 6 for $35 \mathrm{c}$; doz. $60 \mathrm{c} ; 100 \$ 3.00$

\section{INTERMEDIATE AND LATE}

94-AMBASSADEUR-F. deep red, violet, S., lavender, one of the best, each.

$.75 \mathrm{c}$; 3 for $\$ 1.55 ; 6$ for $\$ 2.95$; doz. $\$ 4.50$

80-ARCHEVEQUE-General color is a reddish purple, each

$15 \mathrm{c} ; 3$ for $35 \mathrm{~s} ; 6$ for $55 \mathrm{c}$; doz. $95 \mathrm{c} ; 100 \$ 5.00$

$95-A N N$ FARR-A creamy white, each

$\$ 1.00 ; 3$ for $\$ 2.05 ; 6$ for $\$ 3.95$; doz. $\$ 6.00$

83-ANNA LESLIE-Extra fine flushed rose, each $\$ 1.00 ; 3$ for $\$ 2.05 ; 6$ for $\$ 3.95$; doz. $\$ 6.00$

97-ANN PAGE-A sky blue, one of the finest, each .......................................................... \$5.00

94-BELLERINE-S. light blue, F. deeper biue, very sweet scented, each

$\$ 1.00$; 3 for $\$ 2.05 ; 6$ for $\$ 3.95$; doz. $\$ 6.00$

73-BLUE JAY-A fine blue. each.

$15 \mathrm{c}$; 3 for $35 \mathrm{c}$; 6 for $55 \mathrm{c}$; doz. $95 \mathrm{c} ; 100 \$ 5.60$

75 -CAPRICE-A good red Iris, each.

$.15 \mathrm{c} ; 3$ for $35 \mathrm{c} ; 6$ for $55 \mathrm{c}$; doz. $25 \mathrm{c}$.

s-CA'TERINA-A massive lavender flower, long stem, each .................................50 c; 3 for $\$ 1.05$

70-CHESTER HUNT-S. deep sky blue, F. Marıne blue, each

$25 \mathrm{c} ; 3$ for $60 \mathrm{c} ; 6$ for $95 \mathrm{c}$; doz. $\$ 1.50 ; 100 \$ 8.50$

so-COL. CANDELOT, S. smoky copper, F. crimson, each $75 \mathrm{c} ; 3$ for $\$ 1.55 ; 6$ for $\$ 2.95 ;$ doz. $\$ 4.50$

S6-CLUNY-(Vil, 1920)-S. pale lilac blue, F. deeper blue, each

$.75 \mathrm{c} ; 3$ for $\$ 1.55 ; 6$ for $\$ 2.95$; doz. $\$ 4.50$

ST-CRUSADER-S. light violet blue, F. darker, fragrant, each

$\$ 1.00$; 3 for $\$ 2.05 ; 6$ for $\$ 3.95$; doz. $\$ 4.50$

$\delta 0-E D$. MITCHELL-S. rosy mauve, F. deeper mauve with red border, one of the best red Iris, shy bloomer, each.

.50c; 3 for $\$ 1.05 ; 6$ for $\$ 1.95$; doz. $\$ 3.00$

i\&-ELDORADO-S. yellowish bronze, F. bright violet purple, each.

$25 c$; 3 for $60 \mathrm{c} ; 6$ for $95 \mathrm{c}$; doz. $\$ 1.50$ 
85-GERTRUDE-Clear dark blue, quite early each . ............................................................... $\$ 1.00$

- GLORY OF HILLEGON-Fine shade of bright lavender, each

$25 c$; 3 for 60 c; 6 for $95 c$; doz. $\$ 1.50 ; 100 \$ \delta . \overrightarrow{0} 0$

-GRACCHUS-S. pink, F. yellow, each. $15 \mathrm{c}$; 3 for $35 \mathrm{c}$; 6 for $55 \mathrm{c}$; doz. $95 \mathrm{c} ; 100 \$ 5.00$

7 - - HIAWATHA-S. pale lavender flushed rose, $F$. royal purple, each ..........................30 c; 3 for 65 ; 6 for $\$ 1.15$; doz. $\$ 1.80$; per $100 \$ 10.50$

Ti-INNOCENZA-S. and F. fine waxey white, each $15 \mathrm{c}$; 3 for $35 \mathrm{c}$; 6 for $55 \mathrm{c}$; doz. 95c; per $100 \$ 5.00$

83-INSOLINE-S. flesh lilac, F. old rose, each $.50 \mathrm{c} ; 3$ for $\$ 1.05 ; 6$ for $\$ 1.95$; doz. $\$ 3.00$

-JULIUS CEASAR-S. yellow, F. maroon, each $15 \mathrm{c}$; 3 for $35 \mathrm{c}$; 6 for $55 \mathrm{c}$; doz. $95 \mathrm{c}$; per $100 \$ 5.00$

'it-KHEDIVE-S. and F. beautiful shade of pearly and dark lavender, each

15 c; 3 for 35 c; 6 for $55 c$; doz. 95c; per $100 \$ 5.00$

8:-KING OF IRIS-S. yellow, $F$. maroon, each . .35 c; 3 for 75 c; 6 for $\$ 1.35$; doz. $\$ 2.10$

82-LANEIGE-A good white, slow to increase, each ....50c; 3 for $\$ 1.05 ; 6$ for $\$ 1.95 ;$ Doz. $\$ 3.00$

8:-LEDA-(Fine variety) - Not Farr's variety, a pink mad chereau, each

$.50 \mathrm{c} ; 3$ for $\$ 1.05 ; 6$ for $\$ 1.95$; doz. $\$ 3.0 \mathrm{C}$

93-LENT A. WILLIAMSON-S. lavender violet, F. velvety royal purple, large flower, tall spike, each $\$ 1.00$; 3 for $\$ 2.05 ; 6$ for $\$ 3.95$; doz. $\$ 6.00$

89-LEWIS STROWBRIDGE-S. bright violet, F. blue violet and rose, each.

$50 \mathrm{c} ; 3$ for $\$ 1.05 ; 6$ for $\$ 1.95$; doz. $\$ 3.00$

82-LOHENGRIN-Silvery mauve, large flowar, each .........25c; 3 for $60 c$; 6 for 95c; doz. $\$ 1.50$

86-MAD CHEREAU-. White frilled with a border of lavender, each ....................................25c; 3 for $60 c$; 6 for 95c; doz. $\$ 1.50$; per $100 \$ 8.50$

9-MAGNIFICA - S. bright sky blue, F. long, deep reddish, violet and brown, each ................ $\$ 1.00$

72-MASSASIOTT-S. vermillion blue, F. deeper, very velvety and rich, each $15 \mathrm{c} ; 3$ for $35 \mathrm{c} ; 6$ for $55 \mathrm{c}$; doz. $95 \mathrm{c}$; per $100 \$ 5.00$

80-MAUVINE-Fine distinct shade of mauve or lavender, each

$25 \mathrm{c} ; 3$ for $60 \mathrm{c} ; 6$ for $95 \mathrm{c}$; per doz. $\$ 1.50$

74-MAY QUEEN-Lilac pink, one of the finest pink, each

$25 \mathrm{c} ; 3$ for $60 \mathrm{c} ; 6$ for $95 \mathrm{c}$; doz. $\$ 1.50$

75-MISS E. EARDLY - S. yellow, F. madder red bordered yellow, each

$.25 \mathrm{c} ; 3$ for $60 \mathrm{c}$; 6 for $95 \mathrm{c}$; doz. $\$ 1.50$

84-MONSIGNOR-S. bright sky blue, F. velvecy purple, each $25 c ; 3$ for $60 c ; 6$ for $95 c$; doz. $\$ 1.50 ; 100 \$ 8.50$

90-MOTHER OF PEARL-S. and F. pale bluish lavender, each …............................................. $\$ 1.00$

MRS. G. DARWIN - White with golden violet border, each

$15 \mathrm{c}$; 3 for $35 \mathrm{~s} ; 6$ for $55 \mathrm{c}$ : doz. $95 \mathrm{c}$; per $100 \$ 5.00$

68-MRS. H. DARWIN-Charming free flowering white, each $25 c ; 3$ for $60 c$; 6 for $95 \mathrm{c}$; doz. $\$ 1.50$

$\varepsilon$ i-OPERA-S. bright rich pansy violet, $F$. violet purple, each …….............................................75c

77-OSSIAN-A very fine variegated, each..................

$.15 \mathrm{c}$; 3 for $35 \mathrm{c} ; 6$ for $55 \mathrm{c}$; doz. $95 \mathrm{c}$

-OTHELLO-S. rich blue, F. rich violet purple, one of the latest to bloom, each

$10 \mathrm{c}$; 3 for $24 \mathrm{c}$; 6 for $35 \mathrm{c}$; doz. $60 \mathrm{c}$; per $100 \$ 3.00$ 
9.3-PALIDA DALMATICA-(Sym. Princess Beatrice.) Large clear lavender flower, one of the finest, each

............35c; 3 for $75 \mathrm{c}$; 6 for $\$ 1.35$; doz. $\$ 2.10$

-PALIDA SPECIOSA-Rich lavender purpie, very hardy and strong grower, 3 feet, a good landscape variety, profuse blomer, each $10 \mathrm{c}$; 3 for $24 \mathrm{c}$; 6 for $35 \mathrm{c}$; doz. $60 \mathrm{c} ; 100, \$ 3.00$

79-PARISIANNA-Odd, a mingling of lavender pink, each $25 \mathrm{c}$; 3 for $60 \mathrm{c}$; 6 for $95 \mathrm{c}$; doz. $\$ 1.50$; per $100 \$ 8.50$.

77-POCOHONTAS-Mme. Chereau type, larger and white flower, one of Farr's good ones. It should be rated higher, each....35c; 3 for 75 c; 6 for $\$ 1.35$; doz. $\$ 2.10$; per $100, \$ 12.50$

83-PROSPER LAGUIRE-S. copper crimson, F. deeper, each ................................35c; 3 for $75 \mathrm{c}$ 6 for $\$ 1.35$; doz., $\$ 2.10$; per $100, \$ 12.50$;

72-PRINCESS VICTORIA LOUISE-S. sulphur yellow, F. rich plum, each ................25c; 3 for $60 \mathrm{c} ; 6$ for $95 \mathrm{c}$; doz. $\$ 1.50$, per $100, \$ 8.50$

87-QUAKER LADY-S. smoky lavender, F. ageratum blue, each .............................................35c; 3 for 75 c; 6 for $\$ 1.35$; doz. $\$ 2.10 ; 100, \$ 12.5 \%$

75-QUEEN ALEXANDER-S. lavender, F. pale purple, each ......................................15c; 3 for $35 \mathrm{c} ; 6$ for $55 \mathrm{c}$; doz. 95c; per 100, $\$ 5.01)$

93-QUEEN CATERINA-Pale lavender violet, Self, very fine, each .............................................\$1.00

-RED RIDINGHOOD-(Kochler, 1922.) The nearest approach to red in the Iris family, each $\$ 1.00$

84-RHINE NIXIE-S. white, F. violet purnle, each ...............................................35c; 3 for $55 \mathrm{c}$; 6 for $\$ 1.35$; doz. $\$ 2.10$; per $100, \$ 12.50$

80-SHERWIN WRIGHT-S. nd F. golden yellow, each . . ..........................................................25 ; 3 for $60 \mathrm{c} ; 6$ for $95 \mathrm{c}$; doz. $\$ 1.50 ; 100, \$ 8.50$

-UNDINE-(Kochler 1922) S. deep lavender, F. rich ve!vety purple, each................................\$1.00

80-VIOLACEA GRANDIFLORA-S. and F. Fine clear violet, large flower, each ............25e; 3 for $60 c$; 6 for $95 c$; doz., $\$ 1.50$; per $100 \$ 8.50$ 73-WIND HAM-One of the finest pink Iris, each

$35 \mathrm{c}$; 3 for $75 \mathrm{c}$; 6 for $\$ 1.35$; doz. $\$ 2.10 ; 100 \$ 12.50$

83-WHITE KNIGHT-Absolutely snow white, finest white, each....................................50c; 3 for $\$ 1.0 \mathrm{~s}$

MIXED IRIS 15 for $\$ 1.15$; 18 for $\$ 1.25$; prepaid. per $100 \$ 3.00 \mathrm{~F}$. O. B.

\section{CULTURE.}

Any good rich soil will do, if not work in some bone dust around each plant, about a hand tull. Use no fresh manures of any kind. A light application of lime or wood ashes is beneficial, if not applied too near the plant.

\section{PLANTING.}

We have had good results in transplanting iris aisy time in the growing season, except from about the middle of May to July first which is their blooming season with us. Set the plants so the rhizomies are about level with the ground.

\section{PEONIES}

By all means plant a few peonies. They are one of the hardiest and finest flowers grown. By planting the early, mid-season and late varicties, you may have blooms for a month. 


\section{PLANTING.}

Plant in any good rich soil that is well drained; fartilize the same as for Iris. In setting the plant have the eyes or buds come about level with the ground, as deep planting does not produce many biooms. September until the ground freezes is the best time to plant.

\section{RATING.}

The figures before the names give the rating, 10 being perfect.

8.5-ADOLPH ROUSSEAU-(Dessert, 1890) Early, purple garnet, semi-double, plant tall strong and healthy, free bloomer, each.................\$1.50

8.4-ALBAFLORA-(The Bride) (Dessert, 1902) Early crown type, the finest single white, each

$\$ 1.50$

8.7-AVALANCHE --(Crousse 1886), Late, white flecked carmine with creamy center, medium strong grower and grand flower, each............. $\$ 1.00 ;$ doz. $\$ 9.00$

9.0-BARONESS SCHROEDER-(Kelway, 1889). Mid-season rose type, flesh white fading to milk white, tall and compact, free bloomer,each $\$ 1.25 ;$ doz. $\$ 12.50$

8.1-COURONNA DE ORR--(Calot, 1872), Late, semi-rose, white with crimson splashed, free bloomer and strong grower, each .............\$1.00

7.1-DELACHEI--(Delache, 1856) Mid-season, rose type, rosy Magenta, free bloomer, vigorous grower, each...............................50c; doz. $\$ 5.00$

8.1-DUCHESS DE NEMOURSE-(Calot, 1856). Early crown type, pure white, good grower, free bloomer in clusters, each $75 \mathrm{c}$; doz. $\$ 7.50$

6.9-CANARI-(Guerin, 1861). Mid-season, Blush guards with yellow center, primrose color, each...................50c; 3 for $\$ 1.05$; doz. $\$ 3.50$

7.6-EDULIS SUPERBA-(Lemoine, 1824). Early, crown type, dark, pink free bloomer, strong grower, each $.50 \mathrm{c} ; 3$ for $\$ 1.25$; doz. $\$ 4.50 ; 100, \$ 30.00$

8.6--EUGENIE VERDIER-(Calot, 1864). Mid-season. Semi-rose, hydrangea pink, strong and free bloomer, each .......................................\$1.50

8.4-FELIX CROUSSE-(Crousse, 1881). Mid-season, bombtype, bright red, good grower and free bloomer, each $75 \mathrm{c}$; 3 for $\$ 2.00$; doz. $\$ 7.50$

9.3-FESTAVA MEXIMA-(Miellez, 1851). Very early, Rose type, strong grower and gocd bloomer, each

.50 c; 3 for $\$ 1.25$; doz. $\$ 4.50 ; 100, \$ 30.00$

8.8-GRANDIFLORA (Richardson, 1883), Very late, Rose type, Rose white, a late light pink, each $\$ 1.50 ; 3$ for $\$ 4.00 ;$ doz. $\$ 14.00$

8.2-GROVER CLEVELAND-(Terry, 1904) Late, rose type, dark crimson, good bloomer, each .........................................................\$2.00

8.8-KARL ROSENFIELD--(Rosenfield, 1908). Midseason, semi-rose, dark crimson, free bloomer, strong grower each

$\$ 1.50 ; 3$ for $\$ 4.00 ;$ doz. $\$ 14.00$

9.1-LADY ALEXANDER DUFF-(Kelway, 1902). Early, light rose, shading lighter towards center, large fine flower, each .................\$5.00

9.9-LA CYGNE-(Lemoine, 1907). Mid-season. Semi-rose type, free bloomer, milky white, the highest rated white peony, each.............\$15.00 
8.3-LA ROSIERE-(Crousse, 1888). Mid-season, semi-double, white shading to light cream in center, blooming in clusters, large creamy flower with light yellow center, each cluster a bouquet, each $\$ 1.00$; 3 for $\$ 2.75$; doz. $\$ 9.00$

8.5-MARY LEMOINE-(Calot, 1869). Very late. Rose type, milky white with cream center, strong, blooms freely, each....\$1.00; 3 for $\$ 2.75$

7.9-MAD DUCIL-(Mechin, 1880). Early, bomb type, light mauve rose, free bloomer, strong grower, not good in the South, each.

$75 \mathrm{c}$; 3 for $\$ 2.00$; doz. $\$ 7.00$

8.1-MAD CALOT-(Miellez, 1856). Early rose type, hydrangea pink, good bloomer, strong grower, one of the good ones, each....\$1.00, doz. $\$ 9.00$

7.9-MAD DE VERNVILLE-(Crousse, 1885). Early bomb type, pure white, free bloomer, vigorous grower, each.............75c; 3 for $\$ 2.00$; doz. $\$ 7.00$

7.7-MAD DE VATRY-(Gerrin, 1863). Mid-season, bomb type, large anemone collar, yellowish white center splashed with crimson, free bloomer, each .........75c; 3 for $\$ 2.00$; doz. $\$ 7.00$

8.3-MARY JACQUIN-(Verdier). Semi-double rose white tinged lilac, vigorous bloomer, water lily effect, each....\$1.50; 3 for $\$ 4.00$; doz. $\$ 14.0$ n

9.1-MARTHA BULLOCK-(Brand, 1907). Mid-season. Mammoth cup shape blossom, deep rose pink, shading lighter, blooms freely, vigorous, nine inch blooms are possible, each........\$15.00

7.5-MARECHAL VAILLIANT-(Calot, 1867). Late compact rose type, dark aniline red, strong grower, large flower

75 ; 3 for $\$ 2.00$; doz. $\$ 7.00$

8.6-MIKADO-(Barr, 1893). Early semi-double, the guards are velvety crimson, a well developed cup, pedloids tipped gold, as wonder-ful a flower as you ever beheld, each....\$1.50

9.2-MONS JULES ELI-(Crousse, 1888). Early, bomb type, pale lilac rose, free bloomer, beautiful large blooms, each.

$\$ 1.25 ; 3$ for $\$ 3.50$; doz. $\$ 12.00$

7.6-MONS CHAS LEVEQUE-(Calot, 1861). Midseason crown type, center violet rose with amber yellow anemone collar, blooms freely and strong, each .......................................\$1.25

8.7-PRESIDENT TAFT-(Blaauw, 1909). Mid-season, rose type, delicate hydrangea pink, in a halo of angelic white, fragrant. You will neve: regret buying this lovely peony, each $\$ 2.00 ; 3$ for $\$ 5.25$

6.8-QUEEN VICTORIA-(Whitley, 1808). Mid-sea son. Bomp type, pure milk white, freebloomer, good shipper, each 50c; 3 for $\$ 1.25$, doz. $\$ 4.50$

8.8-RICHARD CARVEL-(Brand, 1913). Very early, bomb type, bright crimson, strong plant, profuse bloomer on tall stems, one of the best of the few early reds, each ……….....\$5.0

9.0-SARAH BARNHART-(Lemoine, 1906). Late Semi-rose, mauve rose silver tipped, strong grower, free bloomer, each $\$ 2.50 ; 3$ for $\$ 6.50$

-SUMMER DAY-(Kelway, 1895). Mid-seasorı, rose type, large flat medium compact flower, white tinted blush, flower five to seven inches, each

-THE MOORE-(Japanese single). Rich glowing crimson, extra fine, each...............................\$1.50 
9.8-THERESE-(Dessert, 1904). Mid-season, rosa type, Violet rose guards and collar slightly splashed crimson, center lilac white, strong plant and medium bloomer, each

$\$ 5.00 ; 3$ for $\$ 13.75$; doz. $\$ 45.00$

8.3-VENUS-(Kelway, 1888). Mid-season, crown type, hydrangea pink, strong grower, blooms freely, very large flower, each

$\$ 2.00,3$ for $\$ 5.25$

9.3-WALTER FAXON-(Richardson, 1904). Midseason, semi-rose, very distinct and delicate bright rose colored flower, free bloomer, each . $\$ 7.50$

Six at one half the dozen rate, 25 at the 100 rate, Each and dozen lots prepaid, 25 and 100 lots, F. O. B.

\section{Hardy Perennials}

Plant a few in your garden or around your house to beautify your home and surroundings, they require very little care and produce an abundance of flowers through the season. Each and dozen lots prepaid, 100 lots shipped by parcel post or express collect, 25 sold at the 100 rate.

COREOPSIS-One of the most popular golden yeilow parennials, each.

$20 \mathrm{c} ; 3$ for $45 \mathrm{c}$; 6 for $75 \mathrm{c}$; doz $\$ 1.20 ; 100, \$ 7.00$

DELPHENIUM-Belladonna, light torquoise blue, each ............................................................. 20 3 for $45 \mathrm{c} ; 6$ for $75 \mathrm{c}$; doz. $\$ 1.20$; per $100, \$ 7.00$

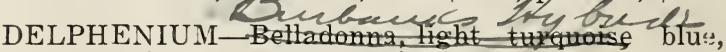
strain of mixed Hybrids, each.....................25c; 3 for $60 \mathrm{c}$; 6 for $95 \mathrm{c}$; doz. $\$ 1.50$; per $100 \$ 8.50$

GAILLARDIA GRANDIFLORA-Blanket flower, 12 to 15 inches high on very long stemmer flowers well above the foliage, color very rich and beautiful. each... $.20 \mathrm{c}$ 3 for $45 \mathrm{c}$; 6 for $75 \mathrm{c}$; doz. $\$ 1.20$; per $100 \$ 7.00$

GAILLARDIAS-Mixed colors, each $.10 \mathrm{c}$ 3 for $24 \mathrm{c}$; 6 for $35 \mathrm{c}$; doz. $60 \mathrm{c}$; per $100 \$ 3.00$

GYPSOPHILA-Peniculata, Fl. Pl. or Baby Breath. The fine mist like flowers are used much in bouquets, each... $.20 \mathrm{c}$ 3 for $45 \mathrm{c}$; 6 for $75 \mathrm{c}$; doz. $\$ 1.20$; per $100 \$ 7.00$

NEW SINGLE HARDY PINK-Miss Gladys Cranfield, two-year-old clumps. The finest English single border pink yet introduced, the plant is of vigorous growth, blooms during May and June, sweet scented, good substance, velvety maroon center, each. .50 c; 3 for $\$ 1.05$; 6 for $\$ 1.95$; doz. $\$ 3.00$

PANSIES-Transplanted last fall, large plants in bloom with dirt on roots, each plant wrapped, selected blooms ready May 1 st to 15 th. each $15 \mathrm{c}$; 3 for $35 \mathrm{c}$; 6 for $55 \mathrm{c}$; doz. $95 \mathrm{c} ; 100 \$ 5.00$, Prepaid.

PANSIES-Seedlings, $\$ 1.50100 ; \$ 121000$, parcel post or express, collect.

PANSIES-Transplanted, $\$ 3.50$ per $100 ; \$ 25.00$ pei 1000 , parcel post, or express collect, 250 at the 1000 rate. 